\title{
Device and method to control turn time in board games
}

\section{Dispositivo y método para controlar el tiempo de turnos en juegos de mesa}

ROJAS-SANDOVAL, Daniel $\uparrow^{*}$, VELASCO-CASTILLO, Miguel Ángel, GIL-VELASCO, Alfredo and HERNÁNDEZ-BÁEZ, Irma Yazmín

\section{Universidad Politécnica del Estado de Morelos}

ID $1^{\text {st }}$ Autor: Daniel, Rojas-Sandoval / ORC ID: 0000-0002-7547-2761, CVU CONACYT ID: 43849

ID $1^{\text {st }}$ Coautor: Miguel Ángel, Velasco-Castillo / ORC ID: 0000-0003-0787-1872, CVU CONACYT ID: 582790

ID 2 $2^{\text {nd }}$ Coautor: Alfredo, Gil-Velasco / ORC ID: 0000-0002-6998-4074, CVU CONACYT ID: 368965

ID $3^{\text {rd }}$ Coautor: Irma Yazmín, Hernández-Báez / ORC ID: 0000-0002-3078-9618, CVU CONACYT ID: 212658

\section{Abstract}

This invention refers to a time controller for up to six users for board games. The device uses a microcontroller and bluetooth module by means of which the number of players and the time of the turns can be configured. This controller indicates by audible and visual signals the current turn, the last seconds and the turn change. The method for counting the turn time guarantees to perform actions by interruptions, generated by the different buttons of the device, using a single microcontroller and with sequential programming.

Timers, Bluetooth, Consumer electronics, Board games

\begin{abstract}
Resumen
Esta invención hace referencia a un controlador del tiempo de hasta seis usuarios para juegos de mesa. El dispositivo utiliza un microcontrolador y módulo bluetooth por medio del cual se puede configurar el número de jugadores y el tiempo de los turnos. Este controlador indica por medio de señales audibles y visuales el turno actual, los últimos segundos y el cambio de turno. El método para contabilizar el tiempo de turno garantiza realizar acciones por interrupciones, generados por los diferentes botones del dispositivo, utilizando un solo microcontrolador y con programación secuencial.
\end{abstract}

Temporizadores, Bluetooth, Electrónica de consumo, Juegos de mesa

Citation: ROJAS-SANDOVAL, Daniel, VELASCO-CASTILlO, Miguel Ángel, GIL-VELASCO, Alfredo and HERNÁNDEZ-BÁEZ, Irma Yazmín. Device and method to control turn time in board games. Journal of Innovative Engineering. 2021. 5-17: 1-5

*Correspondence to Author (e-mail: drojas@upemor.edu.mx)

$\dagger$ Researcher contributing as first Author. 


\section{Introduction}

Board games represent one of the oldest recreational activities in humanity. Some of them, which are played around a board and in which chance is not present, require some time to develop the different game options. As a result, too long turns are generated that generate distraction, boredom and even aversion to this type of game. Using a timer to help add dynamism to board games is an option that has proven valuable in games like chess. They have been developed from mechanical, analog to digital timers to control the time that each player has.

Currently, there are different variants for timers, mainly for games that involve two players with different types or modes of play. Among them are those of chess as in patent US4884255 (A) "Digital chess clock" by Fischer Robert J. In 1988, US4062180 (A) "Electronic chess clock" by Joseph Meshi and Jeffrey R. Ponsor in 1975 or even application; JPS60202381 (A) "Electronic timepiece for game" by Hiroyuki Ishijima in 1984. Although these models allow to control the time (ascending or descending), it is important to note that to start each player has a total time established at the beginning and also, by its application, it is only for two-user games.

Other board game timers developments can be found, only they are for specific games and with limited options. There are for example the application US20140269226 (A1) "Pressure actuated timing apparatus for use with games and the like" by Lowrance Arlen in 2013 [1]. We also find the patent (A) "Games timer" by Ping Wing William Yau in 1996 [2], which shows us a device that controls time in turns with the great disadvantage of having to use a module for each player who is playing. they will have to connect in a wired way and with this, not only occupy most of the space for the dimensions of the average board game, but also; raise costs. Another disadvantage is the configuration of the device, which is currently confusing and slow.

\section{Methodology}

The proposed methodology for the development of the project is shown in Figure 1, which is described below.
1. Research, various sources of information are investigated about the issues related to the project.

2. Design of the electronic system. Once the project requirements have been analyzed, the electronic circuit is designed and the microcontroller is programmed.

3. Design of an application in Android. Develop an application that is easy to interact with the user, integrating the data required by the user to run the device, such as the number of players and the time of the game.

4. Implementation and execution of tests. Verification of the correct functioning of the electronic system with the application.

5. PCB board layout. Once the operation of the electronic system has been verified, the PCB board is made.

6. 3D modeling of the prototype. The prototype is modeled in Solidworks.

7. Implementation of the PCB in the prototype. The necessary $\mathrm{PCB}$ board connections are made in the 3D Model.

8. User manual. A user manual will be developed.

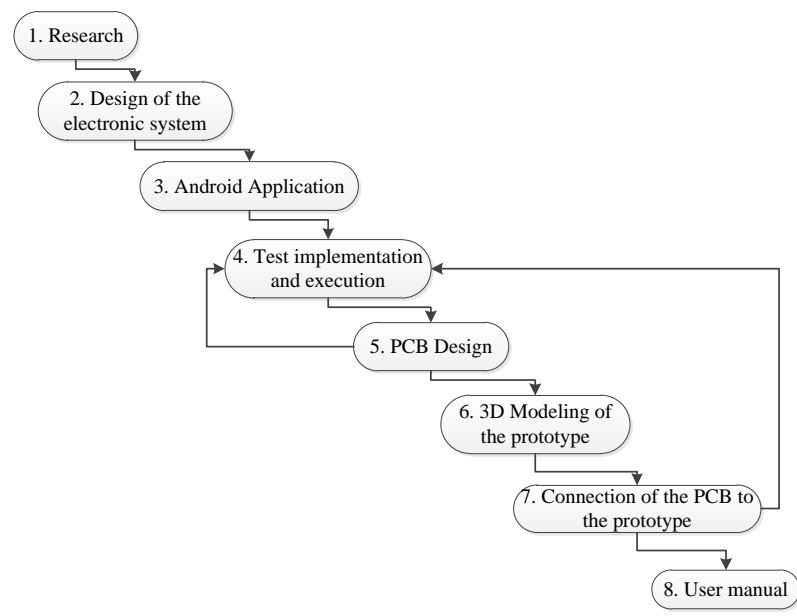

Figure 1 Work methodology

Source: Own Elaboration

For the design of the prototype, a logical structure of the solution is developed as shown in figure 2. 


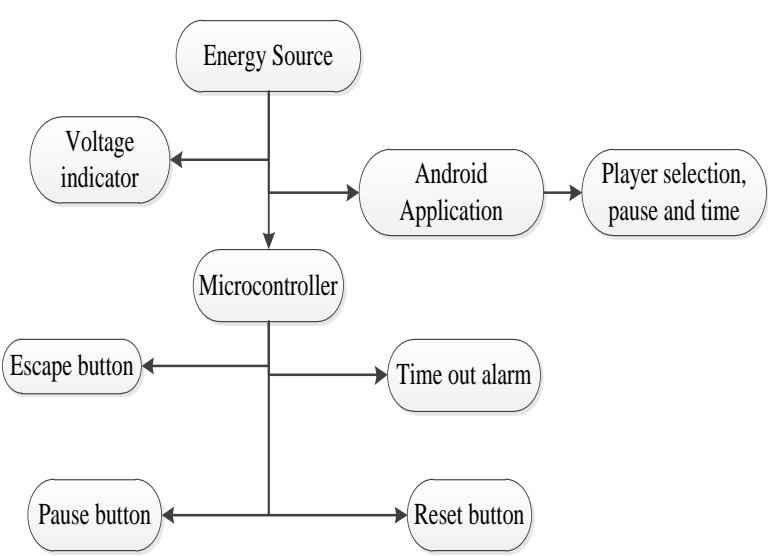

Figure 2 Logical structure of the timer Source: Own Elaboration

As can be seen, it is necessary to differentiate two systems, the electronic system and the 3D model. For the electronic system, a block diagram is designed that is shown in Figure 3, where the different components that make it up are appreciated.

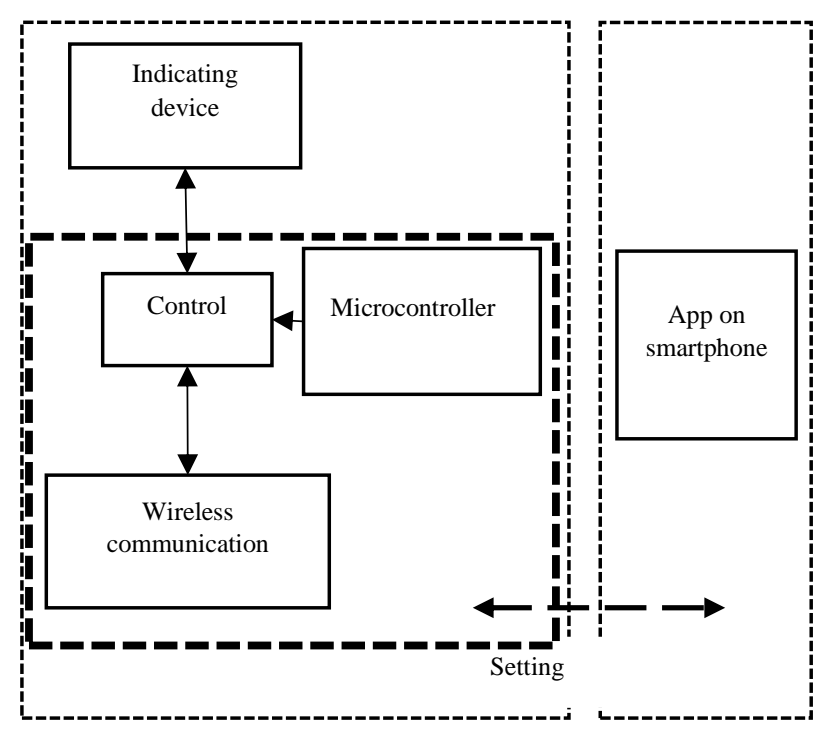

Figure 3 System block diagram Source: Own Elaboration

For the 3D structure, the design shown in Figure 4 is developed, where it can be seen that the timer can control the time of up to six players.

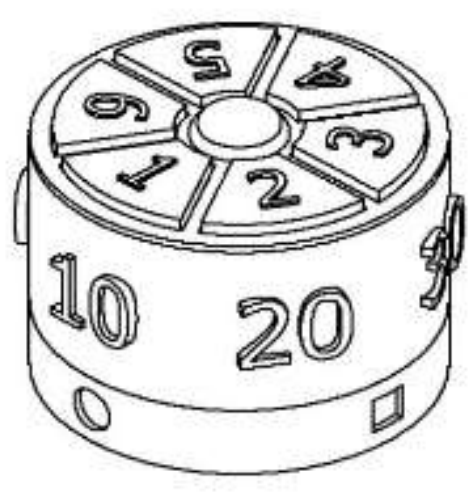

Figure 4 Timer housing

Source: Own Elaboration

The electronic design of the control and communication system is carried out as shown in Figure 5, where an ATMEGA328P-PU microcontroller and an HC-05 Bluetooth module are used. You can also see the indicator LEDs as well as the buzzer for the audible signal for shift changes.

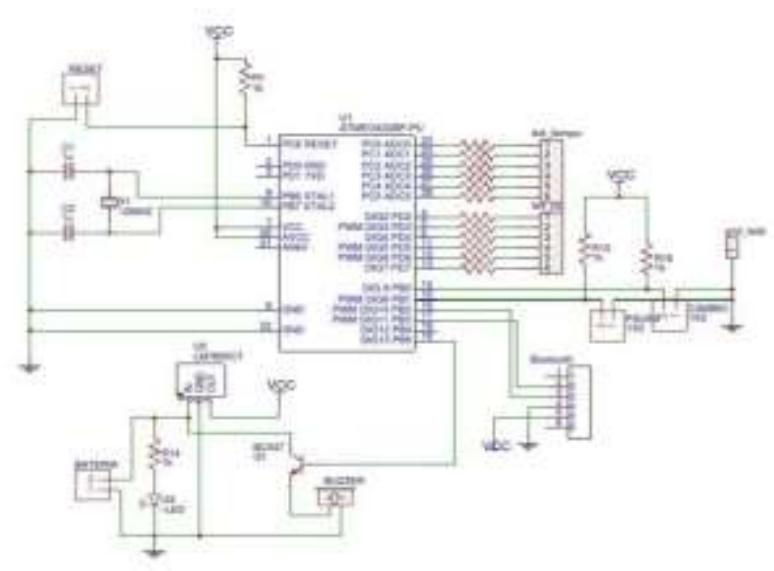

Figure 5 Electronic diagram of the control and communication system

It is important to note that the timer requires three interruptions and the microcontroller only has one, which is used for the Reset function of the system. Therefore, programming, of a sequential type, must be able to identify and perform the interruption at the requested time, namely, for shift change and to pause the system. Figure 6 shows the logic diagram of the microcontroller programming 


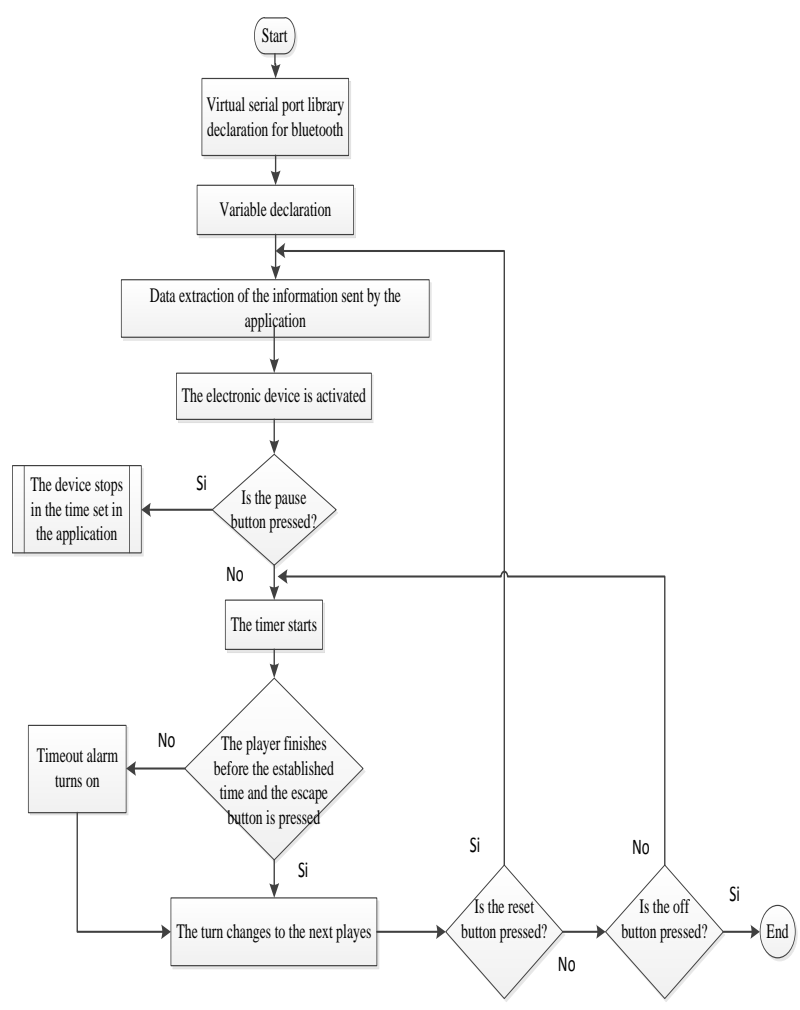

Figure 6 Microcontroller programming flow chart Source: Own Elaboration

For the application on the smartphone, App Inventor is used following the logic shown in Figure 7.
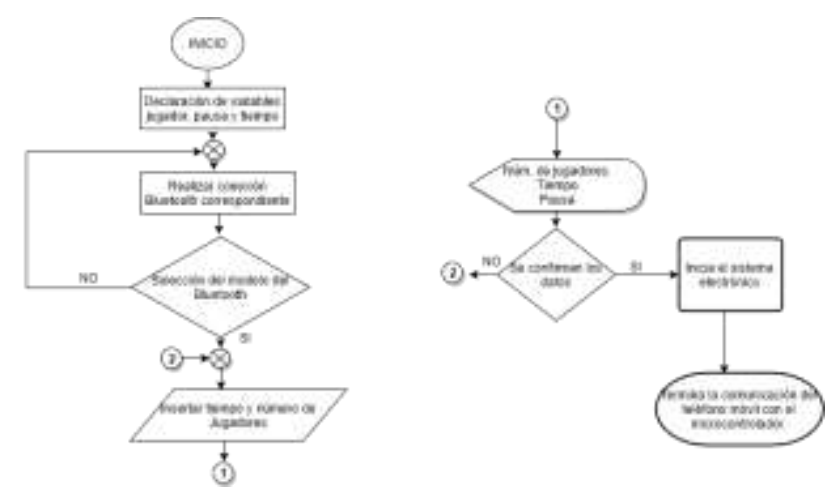

Figure 7 Programming diagram in App Inventor Source: Own Elaboration

The application interface on the smartphone is also shown in Figure 8.

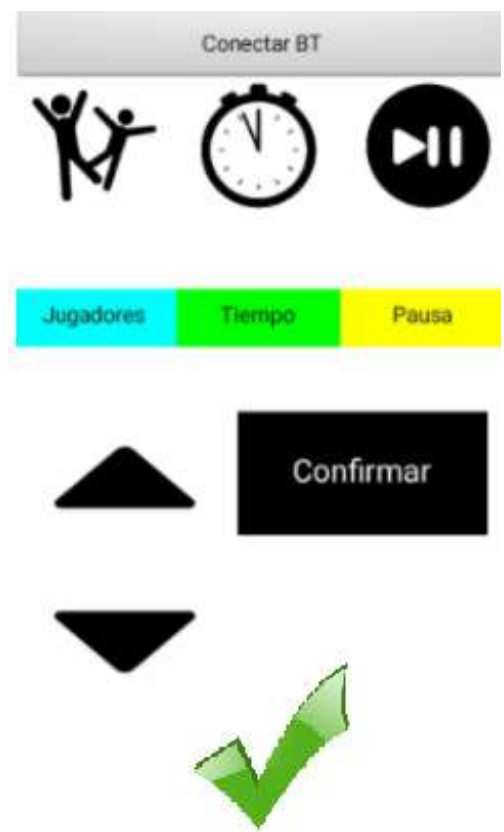

Figure 8 Interface designed in App Inventor Source: Own Elaboration

\section{Results}

It is determined to carry out sensitivity tests of the Bluetooth module within the timer, in order to guarantee connectivity with the smartphone. This is done by setting the spectrum analyzer to a center frequency of $2.4 \mathrm{GHz}$ and the SPAN: 80-100 MHz. During this pairing process, the spectrum analyzer detects a signal at $-53.3 \mathrm{dBm}$ as shown in Figure 8.

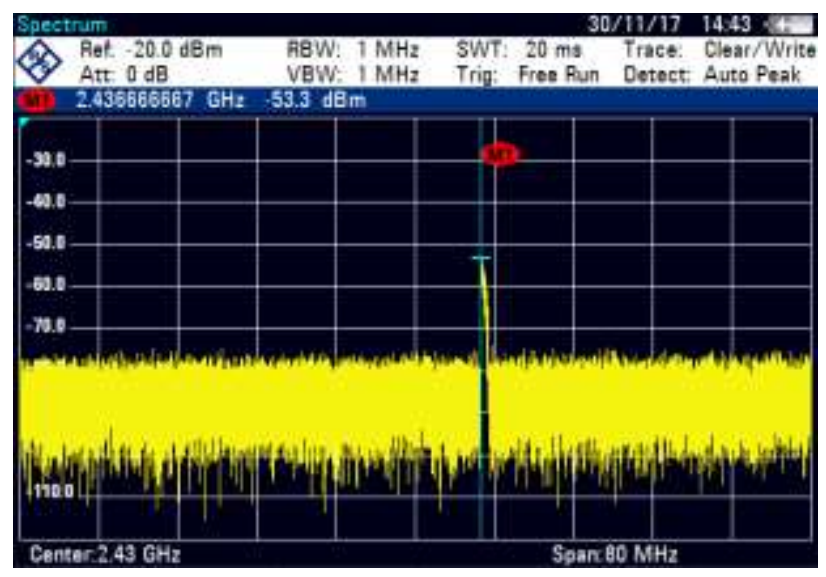

Figure 9 Connection between mobile phone and bluetooth within the prototype

Source: Own Elaboration

This proves that the power is within the stated range and the losses through the filament of the 3D casing of the timer are not significant.

By making the correct configuration of the number of players (from 1 to 6 ), the duration of the turn and the pause time, the device begins the count of the first player's turn.

ROJAS-SANDOVAL, Daniel, VELASCO-CASTILLO, Miguel Ángel, GIL-VELASCO, Alfredo and HERNÁNDEZ-BÁEZ, Irma Yazmín. Device and method to control turn time in board games. Journal of Innovative Engineering. 2021 
The device has light indicators to indicate the player in turn (Figure 10), it has an audible and light signal for the last three seconds of his turn (Figure 12).

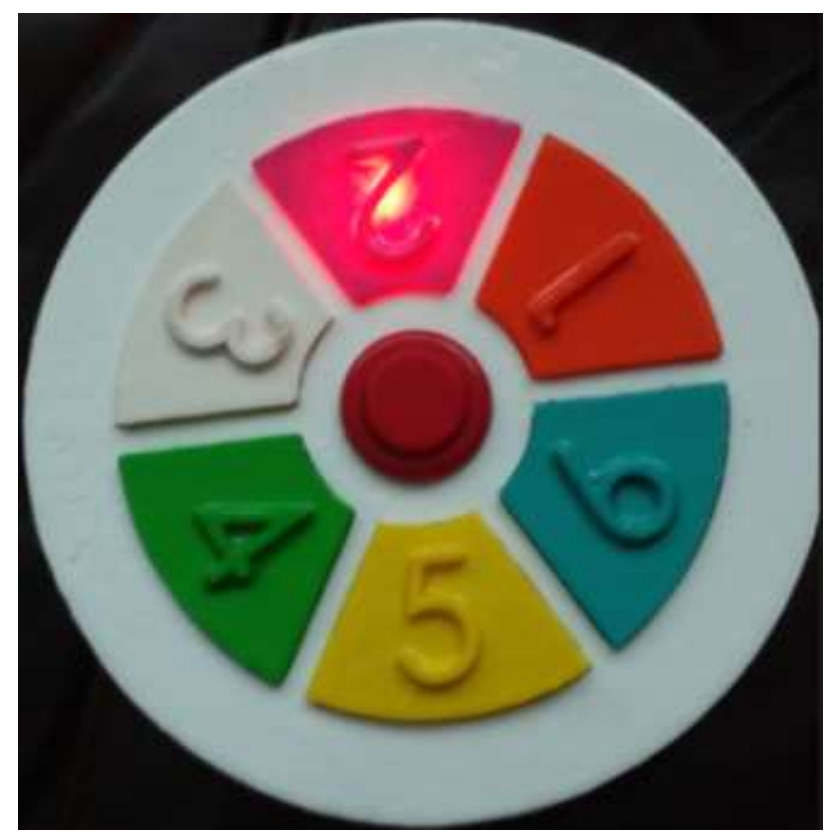

Figure 11 Light signal on player number 2's turn Source: Own Elaboration

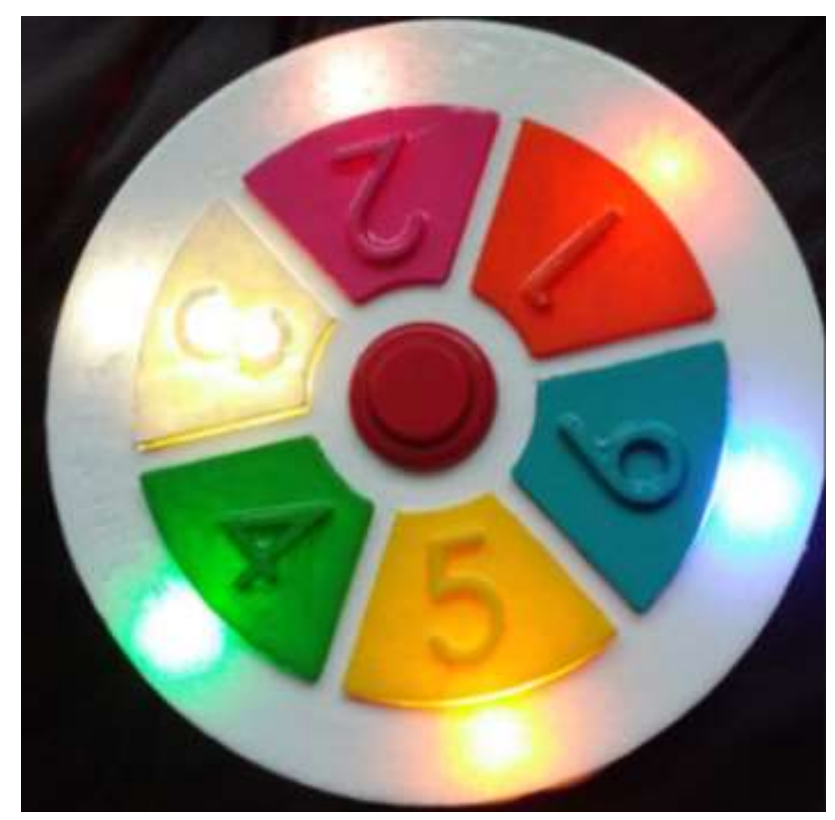

Figure 12 Light signal in the last three seconds of the shift Source: Own Elaboration

In order to measure the level of acceptance of the product, an online form was developed where a non-probabilistic sampling was carried out, since the people who responded to this form were selected through Facebook to 70 residents of the state of Morelos, Chiapas , Chihuahua and the State of Mexico. 85.7\% of respondents find the timer an interesting idea, as shown in Figure 13.
70 Answers
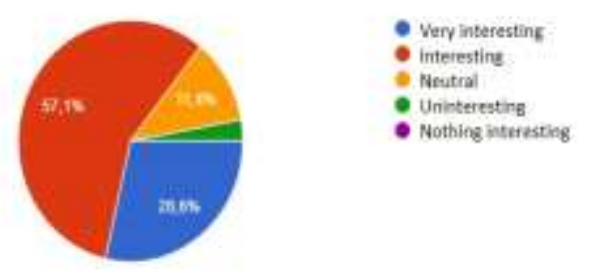

Figure 13 Acceptance of the prototype Source: Own Elaboration

Information was also obtained about aspects of the device, such as ease of use and attractive design, as shown in Figure 14.

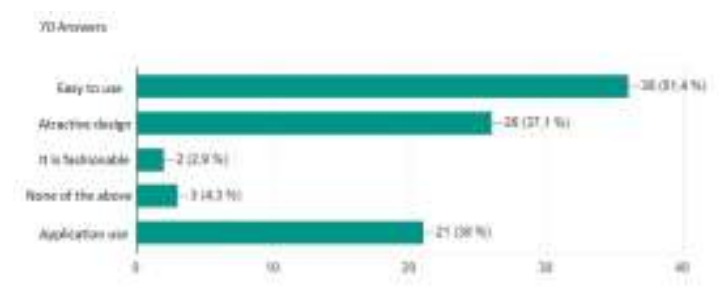

Figure 14 Attractive aspects of the prototype Source: Own Elaboration

$77.1 \%$ of those surveyed state that they would buy the timer in a short time, and $85.5 \%$ consider that by implementing the timer in their board games they would enjoy them more.

\section{Conclusions}

There is a wide variety of board games where this timer can be implemented, such as; domino, scrabble, connect 4 , jenga, rummy, etc; all those where originally the user in turn has free time to make his move. This has negative consequences on the dynamics of these games and they tend to become boring or tedious. On the other hand, by implementing this solution, the game unfolds more dynamic and fun as seen in the responses to the applied survey. As part of future work, it is expected to reduce the size, expand the capacity of players, modify the application interface and design for iOS, use new materials with greater resistance as well as lithium-ion batteries to recharge the product and reduce contamination. to the environment.

\section{References}

L. Arlen, «Pressure actuated timing apparatus for use with games and the like». Patente US20140269226 (A1), 2013.

W. Y. Ping Wing, «Games timer». Patente GB2319637 (A), 1996

ROJAS-SANDOVAL, Daniel, VELASCO-CASTILLO, Miguel Ángel, GIL-VELASCO, Alfredo and HERNÁNDEZ-BÁEZ, Irma Yazmín. Device and method to control turn time in board games. Journal of Innovative Engineering. 2021 